\title{
The unhappily unemployed return to work faster
}

\author{
Dimitris Mavridis
}

\section{Correspondence:}

mavridis.dimitris@gmail.com

Paris School of Economics, Paris,

France

\begin{abstract}
This paper shows that job loss is associated with a fall in subjective well-being (SWB). It then looks at how this change in SWB predicts job search and unemployment duration. The findings suggest that those who report feeling hurt by unemployment have shorter unemployment durations. Men who report a loss of SWB are also more likely to look for a job, but women's job search is not affected by the SWB loss. These findings confirm the theoretical prediction from job search theory: search effort and unemployment duration are affected by the utility differential between having a job and being unemployed.
\end{abstract}

JEL codes: J64; J28

Keywords: Unemployment duration; Job search; Subjective well-being

\section{Introduction}

An important question in labor economics is to what extent unemployment hurts those who experience it, and how large is the difference in utility between having a job and not having one. In job search theory, this difference in utility determines the payoff of the costly job search activity, and the prediction is that the larger the utility gap, the higher the effort one is willing to do to find a job. An opposing view to job search theory sees unemployment as involuntary, driven mostly by labor demand and with little or no role of labor supply. This paper proposes to test which of the two competing theories is true using a panel with data on both subjective well-being (henceforth SWB) and job history. The test consists of checking whether individuals who are (subjectively) most hurt by unemployment are more likely to engage in the costly job activity and more likely to find employment faster.

The prediction from job search theory is that those who experience a larger fall in utility when losing their job should be more likely to be looking for a job. To shed light on this matter, I use the British Household Panel Survey (BHPS), a panel that follows individuals yearly over 16 years and constructs their monthly labor history. The results are as follow. First, I show that SWB drops when individuals lose their job. On average, individuals report a loss of 1.1 in well-being on a $0-12$ scale ( $\frac{1}{3}$ of a standard-deviation), with the loss being slightly higher for men. Behind the average loss, I find large heterogeneity as a significant minority (17\%) reports a rise in utility. Second, I show that this change in SWB

(c) 2015 Mavridis; licensee Springer. This is an Open Access article distributed under the terms of the Creative Commons

Attribution License (http://creativecommons.org/licenses/by/4.0), which permits unrestricted use, distribution, and reproduction in any medium, provided the original work is properly credited. 
predicts both future job search and unemployment duration. The results hold consistently only for men, whereas they disappear under certain specifications for women. For men, the larger the loss of SWB, the more likely they are to look for a job and the less time they spend unemployed, thus confirming that labor supply has a non-negligible role in determining unemployment for them. A further motivation of this paper is to show that SWB variables have a predictive power that can be used to study job search behavior and unemployment duration.

Previous empirical research has focused on the effects of unemployment on mentalhealth but not on whether SWB could help us understand labor supply. Clark (2003) marks an exception, as he also looks into the effect of utility difference on the probability of employment and job search in the next wave. This paper's contribution is to offer a duration model of unemployment to test the theoretical predictions from search theory and to decompose the effects by gender. Recently Gielen and Van Ours (2014) have inquired into this question using German data. Their findings suggest, like mine, that the happiness difference between labor force states predicts job search, but in contrast with my findings, the increase in job search does not translate into shorter unemployment spells. The robustness section uses their methodology to the BHPS data, and I find that my previous results hold: the SWB fall upon entering unemployment not only predicts job search, but also unemployment duration.

The remaining of the paper is organized as follows. Section 2 provides a review of the literature on SWB and labor market status. Section 3 describes the 16 waves of the BHPS as well as the job search and duration data. Section 4 presents the empirical strategy as well as the main results of interest for job search and from the duration model of unemployment. Section 5 concludes.

\section{Literature review}

Studies in happiness and labor have repeatedly found a relationship between employment and happiness. On average, those who lose their job feel significantly worse than when employed, far worse than their income loss would predict ${ }^{1}$.

Prior to economics, a large stream of social psychology research studied the link between SWB and labor status. Most of the works find that employment brings many non-pecuniary benefits. Jahoda (1982) argues that unemployment deprives former workers from social interactions, purposefulness, time structure and the construction of identity. The unemployed are worse off not just because of the loss of their wage income ${ }^{2}$. Earlier empirical work by Jackson et al. (1983) shows that well-being rises with the transition from unemployment to paid work. Although the sample they use is not representative of the population, it highlights the effect of transitions on happiness.

Empirical work from economists testing this view has been conducted since the early 1990s, when reliable data on SWB became available through national household surveys. Clark and Oswald (1994) use the first wave of the BHPS to find that the unemployed are less happy than those working. The "unhappy unemployed" result is also found in Korpi (1997), who uses Swedish data; Winkelmann (1998), who uses the German GSOEP; Woittiez and Theeuwes (1998), who have Dutch data; Frey and Stutzer (2001), who use a Swiss household survey; and Blanchflower (2004) for Britain and the USA. Data on other countries have also been available through the World Values Surveys (WVS) and in other European studies such as those used by Blanchflower (2001) for Eastern and Central 
Europe; and DiTella et al. (2001) for Europe and the USA. All these studies find that when using cross-section data, the unemployed are less happy (on average) than those employed.

Identifying causality from unemployment to happiness is less straightforward. A reverse causality can arise if one is limited to cross section data: it might be easier for happy people to get hired. If inherently happy people are also more productive, better at work or simply more desirable to employers, then it is happiness that positively influences the chances of finding a job, and not the reverse. One way to isolate the causal impact is to use panel data and observe what happens to individuals' happiness as they change labor status ${ }^{3}$. HaiskenDeNew and Kassenböhmer (2009) is among the only studies that identify the causal effect of unemployment on life satisfaction. The authors use 23 waves of a German panel to study the life satisfaction reactions to three different reasons for becoming unemployed: voluntary quit, being fired, and plants closure. Their results suggest that plant closures (which are exogenous) have a strong negative effect on life satisfaction, whereas voluntary quits and being fired do not have significant effects. In this paper, I present panel data on employment transitions, supporting the view that part of the causality goes from labor status to happiness rather than the other way. I also show that the change in happiness caused by the job loss predicts job search effort and unemployment duration.

Looking for a job entails a costly effort, needing investment in readings ads, writing applications, mobilizing one's network, etc. If the utility differences between states (employed and unemployed) is small, it might not be worth suffering the search cost for an outcome that is uncertain. The literature on job mobility provides some evidence supporting this view. For example, Green (2010) finds that workers with a lower job satisfaction are more likely to search for a new job. Similarly, one would expect that those who report a drop in happiness when becoming unemployed will search more and find work quicker. Gielen and Van Ours (2014) test this prediction using a German panel (the GSOEP). Their results are twofold: first, they find that those who suffer when becoming unemployed have a higher likelihood of actively searching for a job. Second, and quite strangely, this increased search activity does not translate into shorter unemployment spells. Small differences in methodology between their paper and mine should be pointed out. The first and most important is their use of life satisfaction as a indicator, while I use SWB. It is known that those two indicators behave differently. For example, Deaton and Kahneman (2010) find that life satisfaction increases monotonically with the log of income, whereas SWB increases until around US\$75,000 and then is flat. A second difference concerns their treatment of the difference in utility between states. In my paper, SWB is a continuous variable, and it follows logically that upon transitions, the difference in SWB is also continuous. Gielen and Van Ours (2014) use a dichotomous variable instead of a continuous one, by creating a dummy for those who have a fall in life satisfaction when losing their job. Some of the variance in the change in life satisfaction is therefore lost in their paper.

\section{Data description}

The dataset used is the British Household Panel Survey (BHPS), collected on households and individuals aged 16 and older, once a year between the months of September and May. It covers a representative sample of the British population during 16 years (19912006) and has almost 10,000 households in 2006. For waves 1 to 8 there are around 10,000 
individual observations by year, whereas for waves $9-16$ there are, on average, 15,000 yearly individual observations ${ }^{4}$. The panel is unbalanced: during the eighteen years of the survey, some households and individual leave while others enter the sample. The survey provides detailed information on individuals' earnings, job history, educational achievement, household characteristics, as well as measures of satisfaction and mental health. From this information, standard control variables are constructed. These include age, educational achievement dummies (low, medium or high), self-assessed health status dummies (excellent, good, poor) as well as civic status (married, never married, separated, divorced or widowed). For comparison purposes, only working-age individuals are kept in the sample (aged between 21 and 65 years).

\subsection{Data on subjective well-being and labor force status}

The measure of well-being used is derived from the General Health Questionnaire (GHQ). This was designed by Goldberg (1972) and is widely used by psychiatrists to assess a person's well-being. The 12 questions asked are provided in the first part of the Appendix ${ }^{5}$. As presented by Argyle (2002), the GHQ is one of the most reliable indicators of psychological distress. Table 1 and Figure 1 present the distribution of GHQ by employment status, and one can note three facts. First, the mean of GHQ is significantly lower for unemployed persons (9.1) as compared to the employed (10.4) or self-employed (10.3). Second, the distribution of GHQ has a larger variance in the unemployed group, where $25 \%$ of the respondents declare a low well-being (defined as a score lower than 8 ) against $13 \%$ and $12 \%$ for the employed and self-employed. Third, the distribution is skewed, with most of the respondents scoring 12, the highest possible grade. Only a quarter (26\%) scores less than 10.

Looking at labor transitions over time, one can observe the associated change in reported SWB. Table 2 reports the effect of labor transitions on the GHQ score. Upon losing their job, those who were employed report, on average, a drop of 1.15 in their SWB, and 1.00 if they were self-employed. This is a significant drop given how the distribution is skewed to the right. The drop corresponds to almost one half of a standard deviation. The transitions from unemployment to employment or self-employment are associated with large increases in well-being (correspondingly 1.38 and 1.15 points). People report feeling better when they return to employment.

There is however an asymmetry in this process. On average, individuals report a larger gain in well-being when returning to work than the loss they report when losing it. A possible explanation for this asymetry is the existence of anticipation and adaptation effects, an approach taken in Hanglberger and Merz (2011), who find large and negative anticipation effects of losing a job. When looking at the same transitional matrix decomposed by

Table 1 GHQ by Labor Status

\begin{tabular}{lccccccc}
\hline Labor Status & Mean GHQ & Std. dev & Observations & p10 & p25 & p50 & \% low GHQ \\
\hline Self-employed & 10,5 & 2,6 & 14711 & 7 & 10 & 12 & 11 \\
Employed & 10,4 & 2,7 & 107587 & 6 & 10 & 12 & 13 \\
Unemployed & 9,1 & 3,6 & 7479 & 3 & 7 & 11 & 25 \\
Total & 10,1 & 3,0 & 182430 & 5 & 9 & 12 & 20
\end{tabular}

Source: BHPS, waves 1-16. Total includes all individuals who are out of the labor force. "Low SWB" is defined as lower than a score of 8 . Means tests confirm that average SWB is different for unemployed and the other two labor categories, at the $1 \%$ level. 


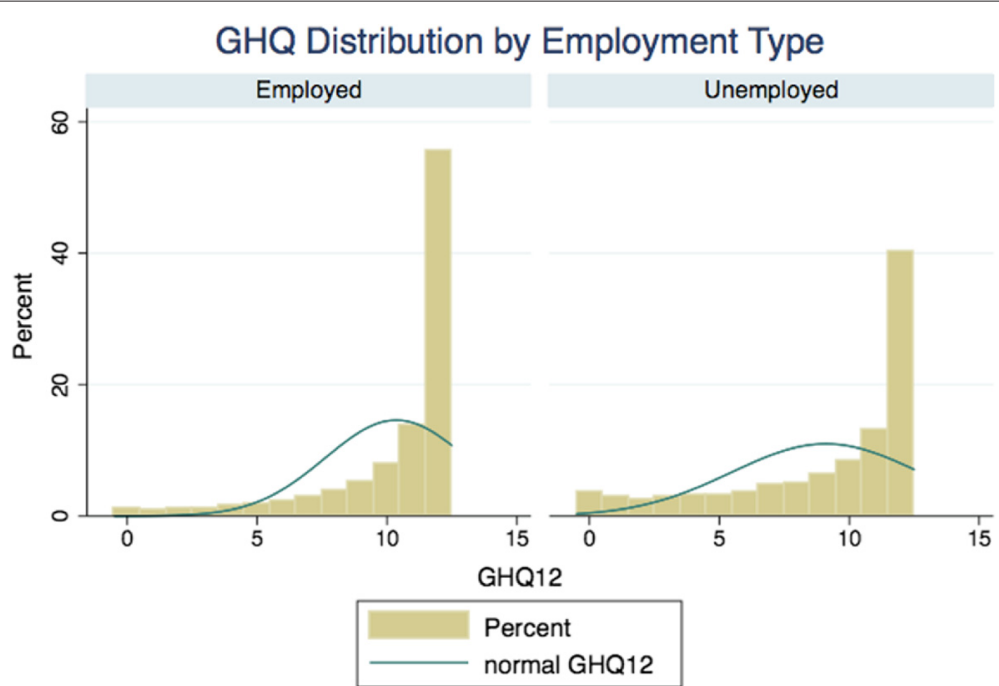

Figure 1 Distribution of GHQ. Source: BHPS, Waves 1-16.

gender, we find that men report higher drops and peaks than women. Transitions from unemployment to employment provide men with a 1.6 jump in SWB compared to a 1.15 for women. When they lose their job, men report a drop of 1.15 points compared to a 1 point drop for women. The transition from self-employment to employment gives much greater rewards to women (0.4 points more) than to men (0.1).

Using this table of transitions, I create a variable that measures the change in happiness when the individual enters unemployment (exiting paid employment), and for simplicity, I call it $\Delta H a p^{6}$. It can be seen as the corollary of $V_{e}-V_{u}$, which in job search theory stands for the utility difference between being employed $\left(V_{e}\right)$ and unemployed $\left(V_{u}\right)$. Figure 2 shows she distribution of $\Delta$ Hap. It reads as follows: $10 \%$ of the individuals report a drop of 1 in well-being when losing their job, while $31 \%$ report feeling no change in their wellbeing. As it is observable, a significant proportion of the individuals report feeling happier than before when losing a job (almost 18\%). The majority, however, reports feeling worse

Table 2 Transition Matrix - Change in Labor Status and in Well-Being

\begin{tabular}{rrrr}
\hline & \multicolumn{3}{c}{ Labor Status in t } \\
\cline { 2 - 4 } Labor Force Status in t-1 & Employed & Unemployed & Self-Employed \\
\hline Employed & -0.04 & & 0.03 \\
Mean & 3.0 & -1.15 & 2.8 \\
sd & 82,478 & 4.0 & 1,774 \\
$\mathrm{~N}$ & & 1,682 & 1.18 \\
Unemployed & 1.38 & & 3.7 \\
Mean & 3.7 & 0.01 & 266 \\
sd & 1,791 & 3.5 & -0.05 \\
$\mathrm{~N}$ & & 2,226 & 2.8 \\
Self-Employed & 0.17 & & 9,970 \\
Mean & 3.0 & -1.00 & 3.7 \\
sd & 1,541 & 212 & \\
$\mathrm{~N}$ & & & \\
\hline
\end{tabular}

Source: BHPS, waves 1-16. 
Change in GHQ in transition from Employment to Unemployment BHPS - Waves 1 to 16

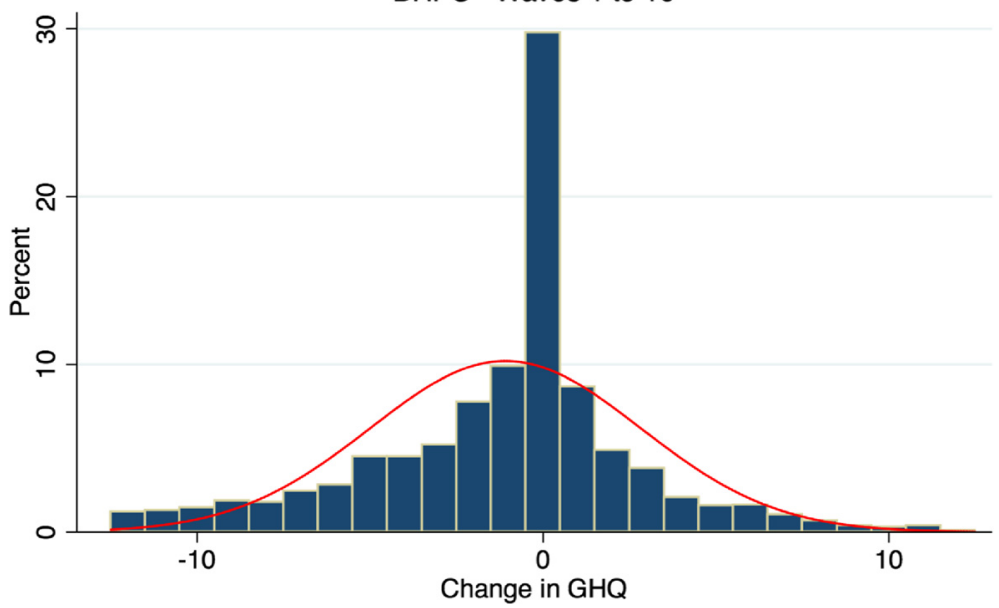

Figure $\mathbf{2} \boldsymbol{\Delta}$ Hap, the change in GHQ following exit from employment. There are 1,635 observation. Mean is -1 ; median is 0 , std-dev is 3.9 .

off (42\%). The average change of well-being is equal to -1.15 , on a 12 points scale. Using $\Delta$ Hap, I split the sample into two groups of individuals: those reporting a loss of happiness (the $42 \%$ of the sample) and those reporting no change or an increase in happiness, and I create a dummy called "loss," which identifies the first group. Table 3 provides a summary of statistics for the variables in the survey.

Table 3 Summary statistics

\begin{tabular}{|c|c|c|c|}
\hline Variable & Mean & Std. Dev. & $\mathrm{N}$ \\
\hline Households in the survey & . & . & 9897 \\
\hline Households in restricted sample & . & . & 7562 \\
\hline Observations in the survey & . & . & 199322 \\
\hline Observations in the restricted sample & . & . & 151567 \\
\hline Male & 0.46 & 0.49 & 151567 \\
\hline Age & 40.9 & 12.58 & 151567 \\
\hline Household Size & 3.01 & 1.33 & 151567 \\
\hline $\mathrm{GHQ}$ & 10.06 & 3.01 & 147786 \\
\hline Married & 0.59 & 0.49 & 151376 \\
\hline Separated & 0.03 & 0.16 & 151376 \\
\hline Divorced & 0.09 & 0.29 & 151376 \\
\hline Widowed & 0.02 & 0.15 & 151376 \\
\hline Never Married & 0.26 & 0.44 & 151376 \\
\hline Health Excellent & 0.25 & 0.43 & 151505 \\
\hline Health Good & 0.48 & 0.5 & 151505 \\
\hline Health Poor & 0.27 & 0.44 & 151505 \\
\hline Educational Achievement: Other & 0.28 & 0.45 & 149779 \\
\hline Educational Achievement: High & 0.39 & 0.49 & 149779 \\
\hline Educational Achievement: Medium & 0.33 & 0.47 & 149779 \\
\hline \multicolumn{4}{|l|}{ Employment Status, in \% of the sample } \\
\hline Self employed & 8.56 & . & 12968 \\
\hline In paid employ & 62.50 & . & 94700 \\
\hline Unemployed & 4.41 & . & 6688 \\
\hline OLF & 24.5 & . & 37171 \\
\hline Job Search (if unemployed) & 0.5 & 0.5 & 6243 \\
\hline
\end{tabular}

Source: BHPS, waves 1-16.

Civic status dummies are Married, Separated, Widowed, Divorced and Never Married. Health dummies are Excellent, Good and Poor. The bottom part of the table shows the number of self-employed, employed and unemployed individuals. 


\subsection{Data on job search}

The BHPS has a section designed in a similar way to the LFS (Labor Force Survey) intended to measure unemployment by the ILO standards. Unemployed individuals are asked if they engaged in any job searching activity in the past week. The answer is self-declared, and their response is limited to Yes/ $\mathrm{No}^{7}$.

Section 4 presents the correlates of job search for those who are unemployed. The results show that men are more likely to report looking for a job than women. Job searching increases with education, age and income, and if one's spouse is employed; it is lower for the divorced and falls when regional unemployment rises (not reported). Individuals receiving higher benefits are less likely to report job search. Finally, the current level of GHQ is not related to the probability of reporting search. This last point is important as it shows that job search and happiness levels are orthogonal.

\subsection{Data on unemployment duration}

The BHPS contains a module with every single employment/unemployment episode from all individuals in the sample, thus providing their entire job history. However, this complete job history is only accessible for the first 16 waves (1991 to 2006). The data is right-censored: information is not available on spells finishing after wave 16. Some random censoring also occurs as individuals are lost during the 16 waves. Merging this data with the household survey allows to run a duration model of unemployment in order to find its main correlates. The 16 years of the sample cover 5,737 unemployment spells ${ }^{8}$. The average duration of a spell is 23 months, but there is great heterogeneity as half of the spells end before the twelfth month and $70 \%$ of them before the $24^{\text {th }}$ month.

Table 4 shows how the average duration in unemployment varies with individuals' characteristics such as their gender, educational achievement, age, or region of residence. For example, women spend, on average, less time unemployed ${ }^{9}$. Unemployment duration is much higher in Scotland, Northern Ireland and Wales than in London and in the South. Younger individuals have shorter spells than older ones, for both genders. Those with a higher educational achievement have, on average, shorter spells (15.4 months) than those with less schooling (32.1 months). Figure 3 shows the survival function of spells decomposed by gender, and Figure 4 decomposes it by educational achievement.

Income and benefits are also related to unemployment duration. We include information on total household income and on individual's own benefits as additional controls for the duration analysis. Benefits are important as they can amount to a substantial percentage of household income ${ }^{11}$. Figures 5 and 3 provide visual evidence of two clear discontinuities in the rate of return to work. The first discontinuity is found in months 10 and 11, in which the rate of return to work is significantly higher than in the immediate preceding or following months. The main suspect for causing this discontinuity is a reduction in benefits occurring on the $12^{\text {th }}$ month. The same story applies for months 22 and 23 as the benefits are also reduced on the $24^{\text {th }}$ month. For some individuals, monetary incentives seem to play a significant role in the rate of return to work. To summarize, age, gender, region and educational achievement all seem to be correlated with unemployment duration. Monetary incentives are also important as the anticipation of a drop in benefits might push some to return to a paid job. These results are in line with the literature on job search behavior. The theoretical model of Mortensen (1977) predicts a 
Table 4 Unemployment Duration, Measured in Months

\begin{tabular}{lccc}
\hline & Men (Std. Dev) & Women (Std. Dev) & All (Std. Dev) \\
\hline Average & $26.9-(31.9)$ & $18.0-(23.7)$ & $23.7-(29.6)$ \\
6 months or less \% & 29.2 & 35.0 & 31.2 \\
12 months or less \% & 46.3 & 61.5 & 51.7 \\
24 months or less \% & 65.4 & 79.6 & 70.4 \\
$\quad$ Region & & & $24.3-(25)$ \\
\hline Inner London & $28.3-(26.1)$ & $18.0-(21.8)$ & $18.2-(23.7)$ \\
Rest SE & $21.9-(27.6)$ & $13.2-(15.7)$ & $17.9-(24.0)$ \\
South West & $21.0-(27.7)$ & $12.1-(12.8)$ & $27.0-(34.3)$ \\
Scotland & $30.9-(37.6)$ & $20.6-(26.7)$ & $26.3-(32.6)$ \\
Wales & $27.6-(32.5)$ & $24.0-(32.7)$ & $26.6-(33.2)$ \\
N. Ireland & $27.2-(33.6)$ & $25.6-(32.6)$ & $30.6-(34.2)$ \\
Age & & & $19.9-(25.8)$ \\
\hline Age $\geq 50$ & $34.9-(37.1)$ & $22.3-(25.8)$ & \\
Age $\leq 35$ & $22.1-(27.3)$ & $15.9-(22.3)$ & $32.1-(34.6)$ \\
Educational Achievement & & & $19.5-(23.9)$ \\
Low & $36.2-(36.6)$ & $23.7-(28.3)$ & $15.4-(21.7)$ \\
Medium & $20.7-(24.7)$ & $17.5-(22.5)$ & \\
High & $18.1-(24.6)$ & $10.5-(13.7)$ &
\end{tabular}

rise in the hazard ratio as one gets closer to the benefits exhaustion time. Meyer (1990) finds evidence of large spikes in the hazard in the prior weeks before exhaustion, a result extensively documented in the literature ${ }^{12}$.

There is an important caveat with respect to the duration data and the main variable of interest, $\triangle$ Hap. GHQ is only recorded once a year at the moment of the interview, while information on labor status is asked for each month of the past year. Given this data design, $\triangle H a p$ is only recorded for the unemployment spells that are running at the moment of the interview. In between two interviews, respondents might have had a short unemployment spell for which the change in happiness is not recorded. Hence, there is an under-representation of short unemployment spells: even though information on 5,737

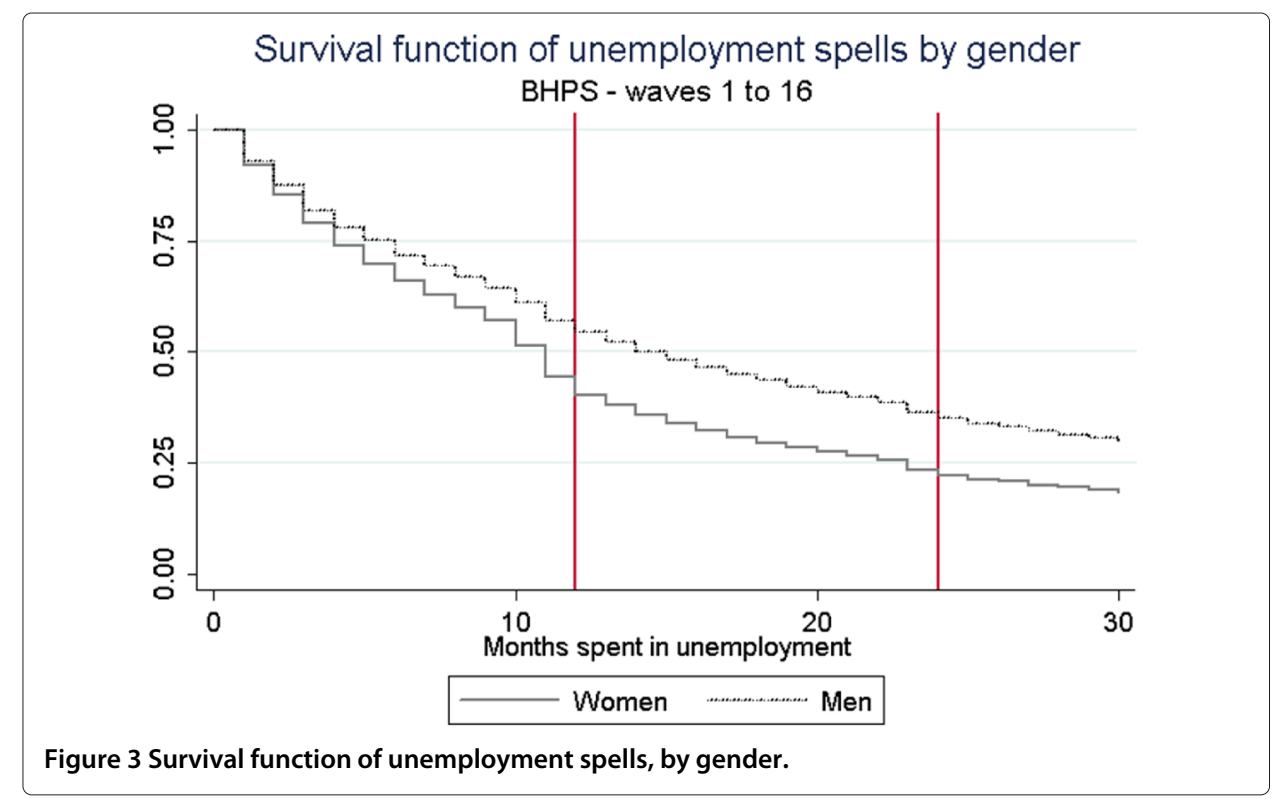




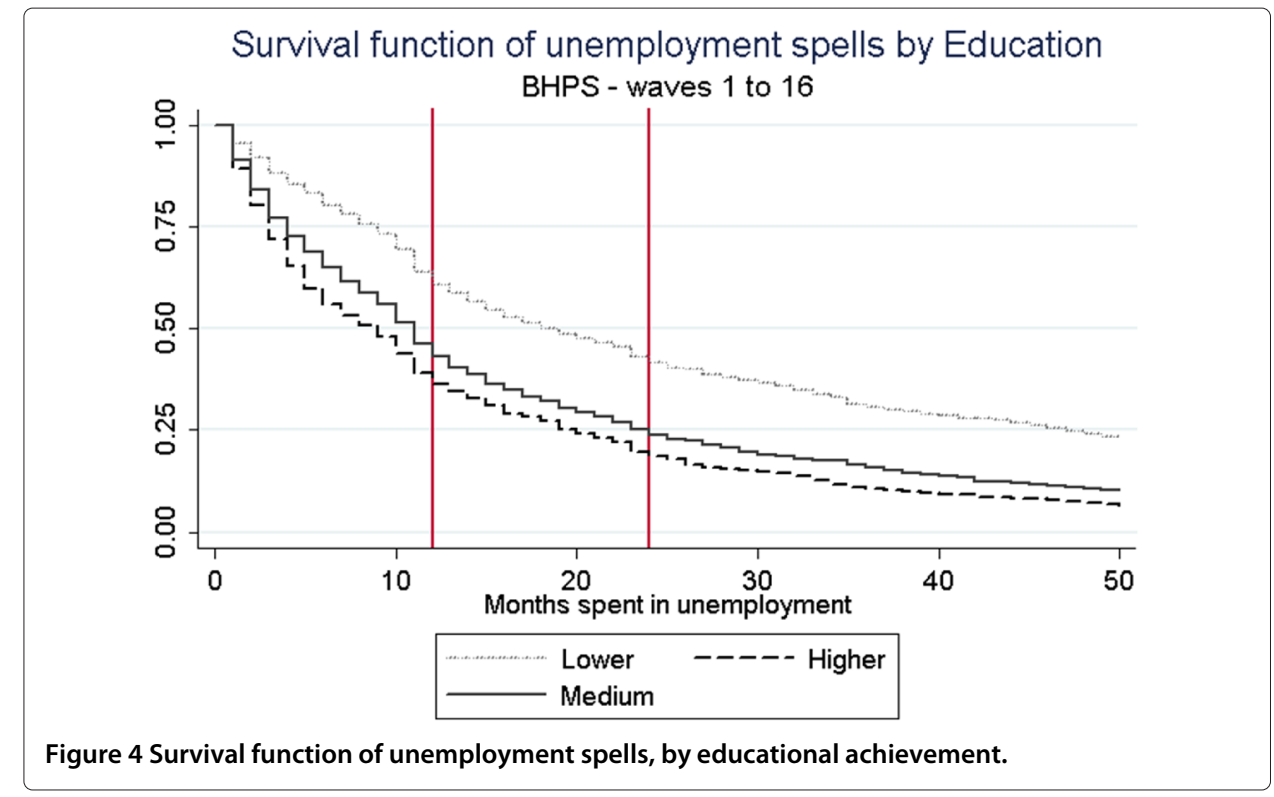

unemployment spells are available, there are only 1,416 observations for the reported changes in well-being. This is due to the fact that data for GHQ is yearly, whereas the unemployment spells are coded monthly. There might be a potential bias to estimating the effect of $\triangle H a p$ on unemployment duration if the (unobserved) $\Delta H a p$ varies during the first 1 to 11 months before the interview. This can be the case if there is a fast habituation effect and those with a longer time in unemployment (up to 11 months) report lower GHQ falls than those who just entered unemployment last month. I address this issue by regressing $\triangle H a p$ on unemployment duration when duration is truncated to 11 months and adding fixed effects to capture the variation on one individual's $\Delta H a p$. The results are in Table 5 and show that after adding fixed effects, $\Delta$ Hap does not vary over the first months before the interview. The robustness section comments more on this table.

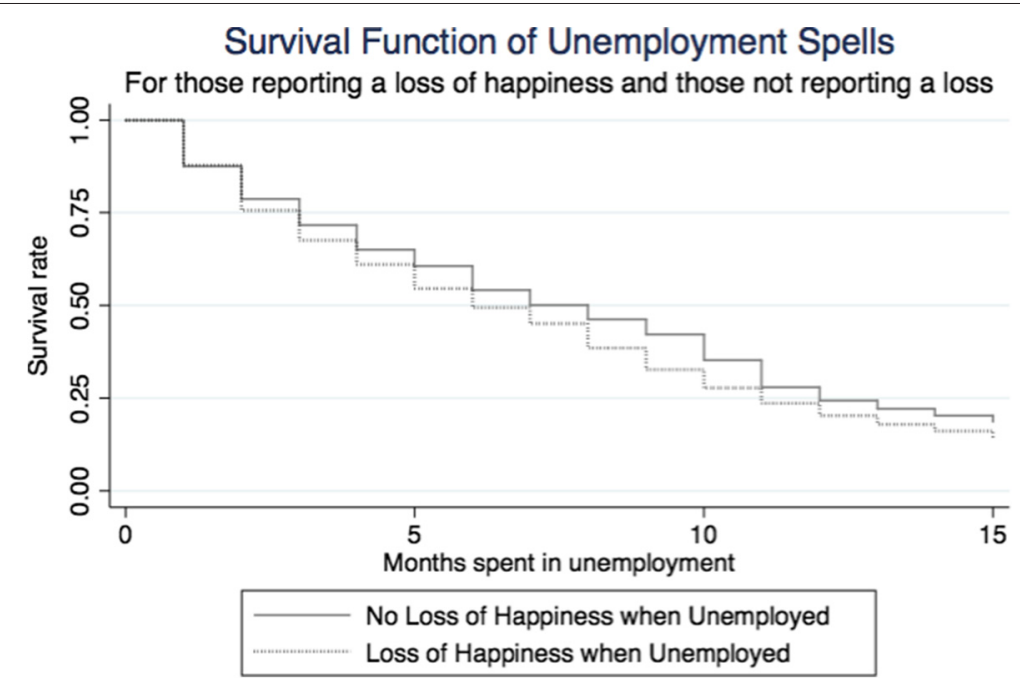

Figure 5 Survival in unemployment for those "suffering" and those "not suffering" upon becoming unemployed. Source: BHPS - waves 1 to 16. 
Table 5 Testing Habituation to unemployment in the first 12 months of unemployment $(2 / 2)$

\begin{tabular}{rcccccc}
\hline & $\begin{array}{c}(\mathbf{7}) \\
\text { d_hap }\end{array}$ & $\begin{array}{c}(\mathbf{8}) \\
\text { d_hap_men }\end{array}$ & $\begin{array}{c}\mathbf{( 9 )} \\
\text { d_hap_wom }\end{array}$ & $\begin{array}{c}\mathbf{( 1 0 )} \\
\text { d_hap_FE }\end{array}$ & $\begin{array}{c}\mathbf{( 1 1 )} \\
\text { d_hap_FE_men }\end{array}$ & $\begin{array}{c}\mathbf{( 1 2 )} \\
\text { d_hap_FE_wom }\end{array}$ \\
\hline ep_duration & 0.0520 & 0.0893 & 0.00179 & 0.170 & 0.0548 & 0.406 \\
& $(0.0548)$ & $(0.0638)$ & $(0.0949)$ & $(0.202)$ & $(0.208)$ & $(0.437)$ \\
Constant & $-1.456^{* * *}$ & $-1.719^{* * *}$ & $-1.106^{* *}$ & $-1.941^{* *}$ & $-1.578^{*}$ & -2.782 \\
& $(0.266)$ & $(0.309)$ & $(0.462)$ & $(0.842)$ & $(0.865)$ & $(1.830)$ \\
Observations & 808 & 453 & 355 & 808 & 453 & 355 \\
R-squared & 0.001 & 0.004 & 0.000 & 0.948 & 0.946 & 0.951 \\
\hline
\end{tabular}

Source: BHPS, waves 1-16. Standard errors in parenthesis, ${ }^{*}$ significant at $10 \%$, ${ }^{*}$ significant at $5 \%$, ${ }^{* * *}$ significant at $1 \%$.

\section{Happiness, job search and unemployment duration}

\subsection{Descriptive statistics}

\subsubsection{Job search}

This section starts by presenting the main correlates of the likelihood of job searching when unemployed, as shown in Table 6. The results highlight the positive correlation

Table 6 Main correlates of job search, marginal probit

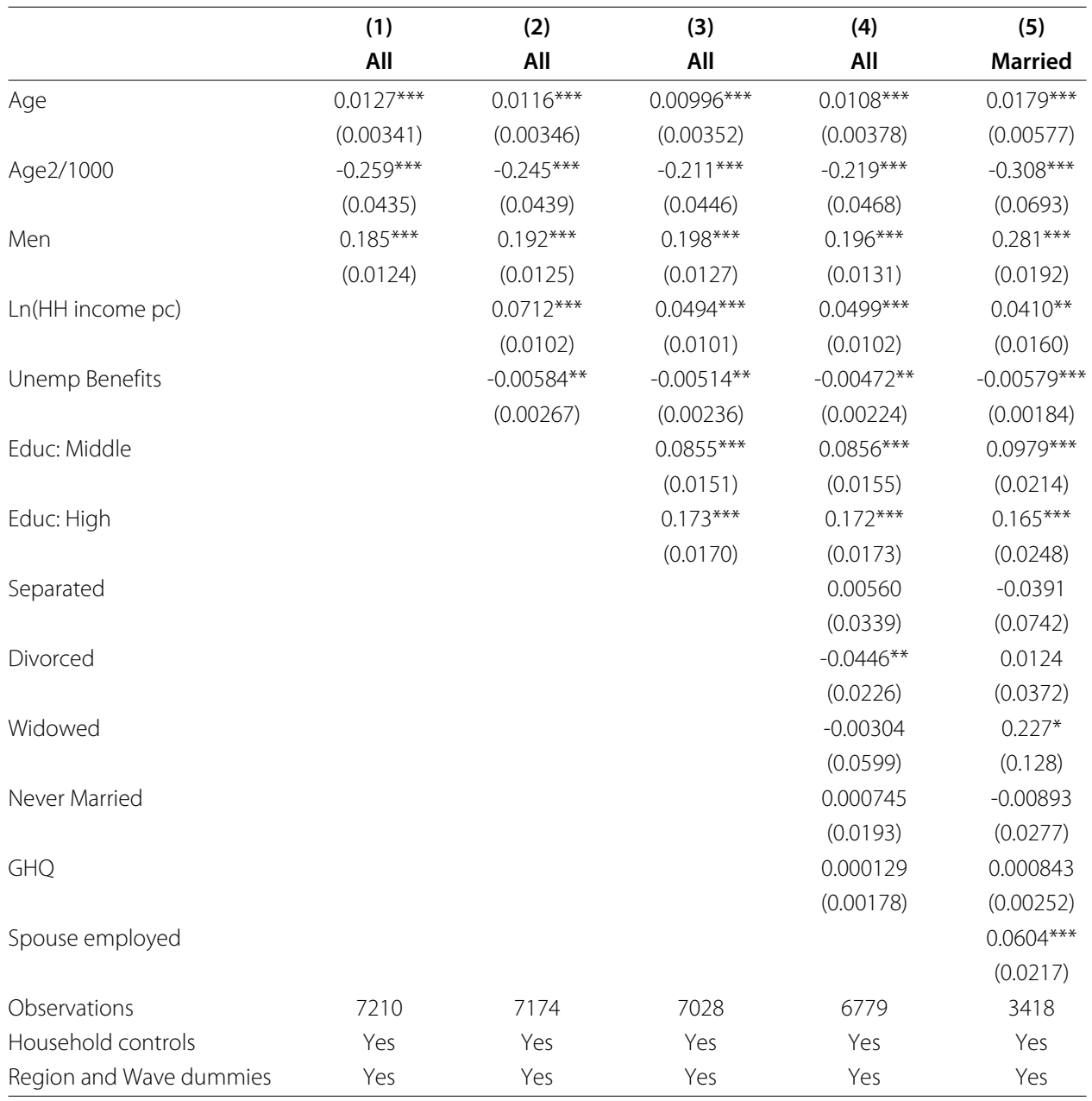

Source: BHPS, waves 1-18. Robust standard errors in parentheses. ${ }^{* *} \mathrm{p}<0.01,{ }^{* *} \mathrm{p}<0.05,{ }^{*} \mathrm{p}<0.1$

The reference category for marital status is "Married", and for education it is "Low".

The dependent variable is constructed from the question: "Have you looked for a job last week?"

Log of Household income per capita is $\ln (\mathrm{HH}$ income). Household controls include size and number of children. 
between job search and education, age, and income levels. This section then focuses on the change in well-being reported upon losing one's job $(\Delta H a p)$ to test whether it affects the duration of unemployment and the probability of searching for a job. Using the dummy loss $^{13}$, I show the differences in job search between the two groups in Table 7. Comparing the means, job search is slightly different between the two groups: $63 \%$ of the group suffering from being unemployed searched for work last week, whereas this drops to $56 \%$ for the others. These results suggest that those being hurt by the job loss are more likely to search than those who do not report a fall in $\mathrm{SWB}^{14}$. A means test (not reported) confirms that both means are different at $95 \%$.

\subsubsection{Kaplan-Meier survival functions}

One piece of evidence suggesting that those who suffer more from the job loss return to work quicker is provided in the Figure 5, in which a Kaplan-Meier survival function is estimated for two different populations using the dummy loss. Figure 5 shows that those who suffer from losing their job leave unemployment more rapidly. The solid grey line (above) estimates the return to work for those who did not suffer from their job loss. The dotted black line (below) is for those who suffered. For the former, the rate of return to work is lower (grey line) than for the latter (dotted line), thus confirming visually that those who report feeling worse at the moment of losing their job are quicker in finding a new job.

The difference in both survival functions is significant at the $80 \%$ level from the fifth month onwards. Hence, this figure provides some visual evidence that the rate of return to work is lower for individuals who report being less hurt from unemployment ${ }^{15}$. Figure 5 also shows that the difference in the rate of exit from unemployment is no longer significant after the eleventh month. This is unlikely to be related to the drop in benefits that occurs at the twelfth month: as we will show in what follows, the change in happiness $\Delta$ Hap does not depend on income or the amount of benefits.

\subsubsection{What predicts $\Delta$ Hap?}

The large heterogeneity of SWB changes to unemployment deserves to be dissected. Among those who lose their jobs, what predicts a rise in happiness, and what predicts a fall? Who are those who become happier when losing their job? Table 8 runs an OLS whose dependent variable is $\Delta$ Hap. The results show that $\Delta$ Hap is not easily linked to any observable characteristic. Individual controls such as gender, educational achievement, age, and marital status are completely orthogonal to the change in happiness when entering unemployment. Household characteristics such as the size and the number of children are also of little help. Income replacement (from benefits) is also, and quite surprisingly, not significant. The only predictor that is significant is the total household income. The larger the household income, the less one is hurt when entering unemployment. The size of the coefficient is however quite small, and its significance holds at the

Table 7 Job Search by Loss

\begin{tabular}{lccc}
\hline Group & Mean & Std. Err (mean). & N.Obs \\
\hline "Loss" & 0.63 & .018 & 669 \\
"No Loss" & 0.56 & .025 & 366 \\
\hline
\end{tabular}

Note: answers to the question: "Have you looked for any kind of paid job in the last week?" can only be Yes or No. 
5\% level. Controlling for the change in income in column 3 does not alter the results, and quite surprisingly, the change in income is not significant either. As a general comparison, column 4 shows the same regressors applied to the year-on-year change in GHQ for all the sample, independently of whether one moves into or out of unemployment. Column 4 shows that the change in income is significant - and of expected positive sign - in the overall population, yet it is strangely not significant in the subsample of those entering unemployment.

The conclusion to be drawn from Table 8 is that unobserved individual-level heterogeneity is very high and that observable characteristics are of little help in predicting the $\triangle$ Hap.

\subsection{Probit of job search}

A probit of "search last week" is presented in Table 9. The coefficient associated to the dummy Loss is significant at the $5 \%$ level in specification (1). The coefficient does not change significantly even after controlling for all individual, household and regional characteristics in specification (2). Specifications (3) and (4) are separated by gender, and this shows that the coefficient is no longer significant for women. Men who suffer when losing their jobs are significantly more likely to search actively for a new job. In what follows, I show that those searching for a job have shorter unemployment durations.

\subsection{Results on unemployment duration}

The average duration of unemployment is also different between those who report a loss in SWB and those who do not report a loss. For the group with a fall in SWB, the average unemployment spell is just below 8 months, whereas those with no fall in SWB report an average unemployment spell of 9.4 months. Using the data on unemployment spells, in this section, I run a duration model, with the aim of explaining the duration of unemployment with a list of controls plus $\Delta$ Hap, the change in happiness reported when entering unemployment. Two estimation strategies are used. The first one is a standard OLS, while the second one is a proportional hazard model. The proportional hazard estimation method used is a Cox model, the standard for duration analysis. A summary of the main results is presented in Table 10, while Tables 11 and 12 show more detailed and complete estimations, which are discussed in the robustness tests section. The results from both estimations (OLS and StCox) are similar in all of the tables presented.

Table 10 shows the OLS and Cox results when regressing the duration in unemployment on the controls and on $\triangle H a p$, which is calculated only for those who were paid employees in the previous year and are unemployed this year ${ }^{16}$. In the OLS estimations (2) to (4), the coefficient for $\Delta$ Hap is positive and significant at the $1 \%$ level, which means that the more an individual says she suffers from losing her job, the quicker she returns to work. The results read as follows: a one point increase in happiness (when losing a job) is associated with around a quarter (0.236) month increase in unemployment duration. The size and significance of $\triangle$ Hap is extremely similar in all estimations, independently of controlling for individual and household level factors, income, or the sample chosen. For example, estimation (4) is reduced to the sample of people who return to work after the unemployment spell, while those who transitioned from unemployment to out of the labor force are not kept in the sample ${ }^{17}$. Estimations (5) to (8) run the proper StCox duration model. 
Table 8 What Explains Diff-Hap? OLS, Dependent variable: Diff Hap

\begin{tabular}{|c|c|c|c|c|}
\hline & $\begin{array}{c}\text { (1) } \\
\text { DiffHap }\end{array}$ & $\begin{array}{c}(2) \\
\text { DiffHap }\end{array}$ & $\begin{array}{c}\text { (3) } \\
\text { DiffHap }\end{array}$ & $\begin{array}{c}\text { (4) } \\
\text { ChgGHQ }\end{array}$ \\
\hline \multirow[t]{2}{*}{ Men } & -0.140 & -0.0334 & -0.00648 & 0.0156 \\
\hline & $(0.207)$ & $(0.214)$ & $(0.217)$ & $(0.0175)$ \\
\hline \multirow[t]{2}{*}{ Educ: Medium } & 0.00161 & 0.0704 & 0.0763 & 0.00403 \\
\hline & $(0.229)$ & $(0.242)$ & $(0.242)$ & $(0.0234)$ \\
\hline \multirow[t]{2}{*}{ Educ: High } & 0.0721 & 0.137 & 0.161 & 0.0125 \\
\hline & $(0.235)$ & $(0.256)$ & $(0.257)$ & $(0.0231)$ \\
\hline \multirow[t]{2}{*}{ Age } & -0.0205 & -0.0281 & -0.0272 & -0.00120 \\
\hline & $(0.0531)$ & $(0.0594)$ & $(0.0594)$ & $(0.00504)$ \\
\hline \multirow[t]{2}{*}{$\mathrm{Age}^{2}$} & $9.74 \mathrm{e}-05$ & 0.000256 & 0.000250 & $2.86 \mathrm{e}-05$ \\
\hline & $(0.000656)$ & $(0.000742)$ & $(0.000741)$ & $(5.99 \mathrm{e}-05)$ \\
\hline \multirow[t]{2}{*}{ Separated } & -0.437 & -0.339 & -0.349 & $0.111^{* * *}$ \\
\hline & $(0.315)$ & $(0.332)$ & $(0.332)$ & $(0.0317)$ \\
\hline \multirow[t]{2}{*}{ Never Married } & -0.0768 & 0.0808 & 0.0787 & 0.0454 \\
\hline & $(0.278)$ & $(0.308)$ & $(0.307)$ & $(0.0289)$ \\
\hline \multirow[t]{2}{*}{ Housing: buyer } & & -0.0733 & -0.0537 & -0.0107 \\
\hline & & $(0.286)$ & $(0.287)$ & $(0.0248)$ \\
\hline \multirow[t]{2}{*}{ Housing: renter } & & $-0.493^{*}$ & -0.480 & 0.0151 \\
\hline & & $(0.299)$ & $(0.300)$ & (0.0289) \\
\hline \multirow[t]{2}{*}{ HHsize } & & -0.0832 & -0.0964 & $-0.0223^{* * *}$ \\
\hline & & $(0.0839)$ & $(0.0843)$ & $(0.00858)$ \\
\hline \multirow[t]{2}{*}{$\mathrm{Nb}$ children } & & 0.256 & 0.272 & $0.0286^{*}$ \\
\hline & & $(0.180)$ & $(0.179)$ & $(0.0156)$ \\
\hline \multirow[t]{2}{*}{ Change Income } & & & $8.93 e-05$ & $2.68 \mathrm{e}-05^{* * *}$ \\
\hline & & & (6.37e-05) & (5.60e-06) \\
\hline \multirow[t]{2}{*}{ Benefit Income } & & $-1.14 \mathrm{e}-06$ & $-7.48 \mathrm{e}-05$ & \\
\hline & & $(0.000493)$ & $(0.000495)$ & \\
\hline \multirow[t]{2}{*}{ Total Income } & & $-2.39 e-05^{* *}$ & $-2.22 \mathrm{e}-05^{*}$ & \\
\hline & & $(1.20 \mathrm{e}-05)$ & $(1.20 \mathrm{e}-05)$ & \\
\hline \multirow[t]{2}{*}{ Constant } & -0.240 & 0.429 & 0.501 & 0.00275 \\
\hline & $(1.054)$ & $(1.407)$ & $(1.406)$ & $(0.128)$ \\
\hline Observations & 1,634 & 1,616 & 1,616 & 128,334 \\
\hline R-squared & 0.004 & 0.027 & 0.028 & 0.001 \\
\hline Individual Controls & Yes & Yes & Yes & Yes \\
\hline Household Controls & No & Yes & Yes & Yes \\
\hline Income & No & Yes & Yes & Yes \\
\hline Region Dummies & No & Yes & Yes & Yes \\
\hline
\end{tabular}

Again, the coefficient for $\triangle$ Hap is not affected by the inclusion of household controls or income (from benefits and total income). The coefficient for benefits indicates that the higher the benefits, the longer the duration of unemployment; while the coefficient for total income shows that in households with higher total income, the duration of unemployment is lower. Including income as a control takes away the educational differences in duration. Specification (7) adds an interaction of $\Delta$ Hap and gender. The coefficient for $\Delta$ Hap is still significant and of the same sign, while the interaction is not significant. The results therefore suggest that those who report feeling worse upon losing their job are 
Table 9 Do the unhappily unemployed search for work?

\begin{tabular}{lcccc}
\hline & $(\mathbf{1})$ & $\mathbf{( 2 )}$ & $\mathbf{( 3 )}$ & $\mathbf{( 4 )}$ \\
& Basic & All controls & Men & Women \\
\hline Loss & $0.0611^{* *}$ & $0.0582^{* *}$ & $0.0894^{* * *}$ & -0.00637 \\
Age & $(0.0284)$ & $(0.0286)$ & $(0.0346)$ & $(0.0476)$ \\
& $-0.00337^{* * *}$ & $-0.00365^{* *}$ & $-0.00463^{* *}$ & -0.00184 \\
Male & $(0.00123)$ & $(0.00156)$ & $(0.00188)$ & $(0.00268)$ \\
& $0.189^{* * *}$ & $0.192^{* * *}$ & & \\
Educ: Middle & $(0.0289)$ & $(0.0294)$ & & \\
& $0.0833^{* *}$ & $0.0766^{* *}$ & 0.0132 & $0.203^{* * *}$ \\
Educ: High & $(0.0339)$ & $(0.0343)$ & $(0.0410)$ & $(0.0603)$ \\
& $0.0722^{* *}$ & $0.0754^{* *}$ & 0.0379 & $0.135^{* *}$ \\
Observations & $(0.0343)$ & $(0.0345)$ & $(0.0432)$ & $(0.0568)$ \\
Household controls & 1238 & 1235 & 755 & 480 \\
Region dummies & No & Yes & Yes & Yes \\
Unemployment rate & No & Yes & Yes & Yes \\
\hline
\end{tabular}

Standard errors in parentheses. ${ }^{* *} \mathrm{p}<0.01,{ }^{* *} \mathrm{p}<0.05,{ }^{*} \mathrm{p}<0.1$. HH controls are marital status and household size. Dependent variable is answer to "Have you looked for any kind of paid job last week?", which is a 0/1 dummy.

Table 10 Dependent variable: duration in unemployment, measured in months

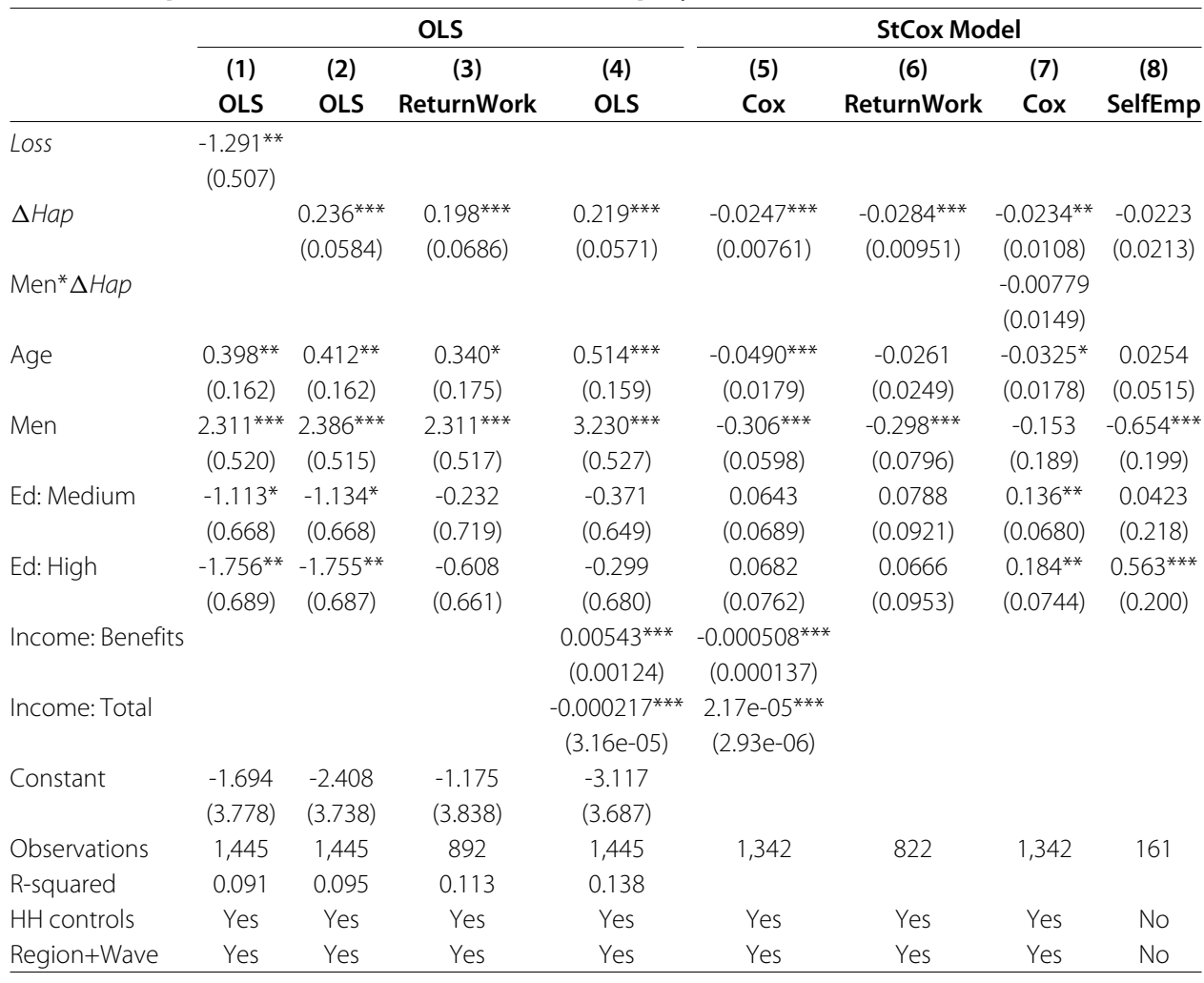

Source: BHPS, waves 1-16, pooled data. Absolute value of $t$ stat in parentheses. ${ }^{*}$ significant at $10 \%$, ${ }^{*}$ significant at $5 \%$, ***significant at $1 \%$. The reference category for education is low educational achievement. Household controls include size, number of children, and marital status. Loss is a dummy $=1$ when an individual reports a loss of happiness upon losing his job. $\Delta$ Hap measures the initial change in happiness when becoming unemployed. Given that most observations of Diff-hap are negative, the results have to be interpreted as follows: if happier about losing a job, then one spends more time in unemployment.

Column "ReturnWork" is based on the sample of individuals who return to work after their unemployment spell. 
Table 11 Dependent variable: duration in unemployment, measured in months

\begin{tabular}{|c|c|c|c|c|c|c|c|c|}
\hline & $\begin{array}{l}\text { (1) } \\
\text { ols }\end{array}$ & $\begin{array}{l}\text { (2) } \\
\text { ols }\end{array}$ & $\begin{array}{l}\text { (3) } \\
\text { ols }\end{array}$ & $\begin{array}{l}\text { (4) } \\
\text { ols }\end{array}$ & $\begin{array}{c}(5) \\
\text { stcox }\end{array}$ & $\begin{array}{c}(6) \\
\text { stcox }\end{array}$ & $\begin{array}{c}(7) \\
\text { stcox }\end{array}$ & $\begin{array}{c}(8) \\
\text { stcox }\end{array}$ \\
\hline \multirow[t]{2}{*}{ Age } & $0.487^{* *}$ & 0.114 & 0.319 & 0.337 & $-0.0257^{* * *}$ & -0.00759 & -0.0296 & -0.0314 \\
\hline & $(0.209)$ & $(0.317)$ & $(0.221)$ & $(0.221)$ & $(0.00791)$ & $(0.0116)$ & $(0.0248)$ & $(0.0248)$ \\
\hline \multirow[t]{2}{*}{ Age sq. } & -0.00270 & $1.14 \mathrm{e}-06$ & -0.00340 & -0.00359 & $0.000193^{*}$ & $4.38 \mathrm{e}-05$ & 0.000331 & 0.000350 \\
\hline & $(0.00263)$ & $(0.00387)$ & $(0.00263)$ & $(0.00263)$ & $(9.95 e-05)$ & $(0.000141)$ & $(0.000296)$ & $(0.000296)$ \\
\hline \multirow[t]{2}{*}{ Male } & $7.897^{* * *}$ & $6.016^{* * *}$ & $1.851^{* * *}$ & $1.951^{* * *}$ & $-0.309^{* * *}$ & $-0.267^{* * *}$ & $-0.228^{* * *}$ & $-0.238^{* * *}$ \\
\hline & $(0.770)$ & $(1.168)$ & $(0.667)$ & $(0.667)$ & $(0.0287)$ & $(0.0425)$ & $(0.0758)$ & $(0.0758)$ \\
\hline \multirow[t]{2}{*}{ Educ. Medium } & $-9.664^{* * *}$ & $-8.614^{* * *}$ & $-1.469^{*}$ & $-1.508^{*}$ & $0.333^{* * *}$ & $0.287^{* * *}$ & $0.154^{*}$ & $0.158^{*}$ \\
\hline & $(0.890)$ & $(1.244)$ & $(0.783)$ & $(0.782)$ & $(0.0331)$ & $(0.0451)$ & $(0.0874)$ & $(0.0873)$ \\
\hline \multirow[t]{2}{*}{ Educ. High } & $-13.43^{* * *}$ & $-11.14^{* * *}$ & $-2.288^{* * *}$ & $-2.327^{* * *}$ & $0.548^{* * *}$ & $0.481^{* * *}$ & $0.216^{* *}$ & $0.226^{* *}$ \\
\hline & $(0.922)$ & (1.349) & $(0.804)$ & $(0.804)$ & $(0.0344)$ & $(0.0489)$ & $(0.0905)$ & $(0.0905)$ \\
\hline \multirow[t]{2}{*}{ Reg. Un } & $1.142^{* * *}$ & $1.080^{* * *}$ & $0.453^{* * *}$ & $0.456^{* * *}$ & $-0.0463^{* * *}$ & $-0.0458^{* * *}$ & $-0.0401^{* * *}$ & $-0.0405^{* * *}$ \\
\hline & $(0.143)$ & $(0.203)$ & $(0.119)$ & $(0.118)$ & $(0.00538)$ & $(0.00750)$ & $(0.0136)$ & $(0.0136)$ \\
\hline \multirow[t]{2}{*}{ Ben.Inc. } & $0.0110^{* * *}$ & $0.0153^{* * *}$ & $0.00566^{* * *}$ & $0.00565^{* * *}$ & $-0.000716^{* * *}$ & $-0.000479^{* * *}$ & $-0.000464^{* *}$ & $-0.000465^{* *}$ \\
\hline & (0.00109) & (0.00209) & $(0.00153)$ & (0.00153) & $(5.83 e-05)$ & $(7.93 e-05)$ & $(0.000191)$ & $(0.000192)$ \\
\hline \multirow[t]{2}{*}{ Sp. Unmp } & & $9.156^{* * *}$ & $1.396^{* *}$ & $1.465^{* *}$ & & $-0.355^{* * *}$ & $-0.189^{* *}$ & $-0.188^{* *}$ \\
\hline & & $(1.166)$ & $(0.708)$ & $(0.708)$ & & $(0.0424)$ & $(0.0810)$ & $(0.0809)$ \\
\hline \multirow[t]{2}{*}{ Loss } & & & $-2.275^{* * *}$ & & & & $0.225^{* * *}$ & \\
\hline & & & $(0.630)$ & & & & $(0.0717)$ & \\
\hline \multirow[t]{2}{*}{$\Delta H a p$} & & & & $0.298^{* * *}$ & & & & $-0.0309^{* * *}$ \\
\hline & & & & $(0.0802)$ & & & & $(0.00898)$ \\
\hline Reg. dummies & Yes & Yes & Yes & Yes & Yes & Yes & Yes & Yes \\
\hline Constant & Yes & Yes & Yes & Yes & & & & \\
\hline Observations & 5725 & 3030 & 885 & 885 & 5501 & 2909 & 824 & 824 \\
\hline R-squared & 0.122 & 0.146 & 0.092 & 0.093 & & & & \\
\hline
\end{tabular}

Source: BHPS, waves 1-16, pooled data. Standard errors in parenthesis, ${ }^{*}$ significant at $10 \%$, ${ }^{* *}$ significant at $5 \%$, ***significant at $1 \%$. The reference category for education is low educational achievement.

Loss is a dummy $=1$ when an individual reports a loss of happiness larger than 1 point when losing his job.

$\Delta$ Hap measures the initial change in happiness when becoming unemployed. Given that most observations of Diff-hap are negative, the results have to be interpreted as follows: if happier about losing a job, then one spends more time in unemployment.

faster in leaving unemployment. Both OLS and StCox models suggest a negative relationship between duration in unemployment and the "happiness drop". The larger $V_{e}-V_{u}$ (the happiness drop an individual reports between being employed and unemployed), the shorter his unemployment duration will be. As an illustration, consider the coefficient in estimation (1). It shows that those who reported a fall in happiness spent 1.3 months less in unemployment ${ }^{18}$.

\subsubsection{Robustness checks}

In Table 11, a series of robustness checks confirms the previous results. First, I check if $\Delta H a p$ is still significant when including more controls. I control for the regional jobless rate as it is also likely to affect time spent looking for work. If more people compete to get jobs, average search duration should increase. As shown in the empirical literature, unemployment benefits should also increase duration because they have an effect on the reservation wage. I also add a dummy for unemployed spouse in specifications (2) and (6). As a final check, I use the dummy loss in specifications (3) and (7), and the results are also significant. 
Table 12 Duration of unemployment when controling benefits, job search and income

\begin{tabular}{lccccccc}
\hline & $(\mathbf{1})$ & $\mathbf{( 2 )}$ & $\mathbf{( 3 )}$ & $\mathbf{( 4 )}$ & $\mathbf{( 5 )}$ & $\mathbf{( 6 )}$ & $\mathbf{( 7 )}$ \\
& All & All & All & All & All & Women & Men \\
\hline Search & & $0.177^{* * *}$ & $0.190^{* *}$ & $0.128^{* *}$ & & & \\
& & $(0.0616)$ & $(0.0796)$ & $(0.0627)$ & & & \\
$\Delta$ Hap & $-0.0254^{* * *}$ & $-0.0302^{* * *}$ & $-0.0333^{* * *}$ & $-0.0285^{* * *}$ & $-0.0255^{* * *}$ & -0.0198 & $-0.0290^{* *}$ \\
& $(0.00712)$ & $(0.00763)$ & $(0.00947)$ & $(0.00762)$ & $(0.00894)$ & $(0.0136)$ & $(0.0123)$ \\
Log (Benefits) & & & $-0.125^{* *}$ & & $-0.156^{* * *}$ & 0.0170 & $-0.288^{* * *}$ \\
& & & $(0.0512)$ & & $(0.0478)$ & $(0.0703)$ & $(0.0747)$ \\
Log (real yearly income) & & & & $0.260^{* * *}$ & $0.270^{* * *}$ & $0.187^{* *}$ & $0.384^{* * *}$ \\
& & & & $(0.0401)$ & $(0.0527)$ & $(0.0817)$ & $(0.0727)$ \\
Observations & 1344 & 1180 & 772 & 1160 & 842 & 343 & 499 \\
Standard controls & Yes & Yes & Yes & Yes & Yes & Yes & Yes \\
Region and Wave & Yes & Yes & Yes & Yes & Yes & Yes & Yes \\
\hline
\end{tabular}

Source: BHPS, waves 1-16. Standard errors in parenthesis, ${ }^{*}$ significant at $10 \%,{ }^{* *}$ significant at $5 \%,{ }^{* * *}$ significant at $1 \%$. All specifications above are from a duration model using the StCox procedure.

Standard controls include age, age squared, gender, number of children, household size, dummies for education and dummies for marital status. Region and Wave dummies are added in all specifications.

Diff-hap measures the initial change in happiness when becoming unemployed. Given that most observations of Diff-hap are negative, the results have to be interpreted as follows: if happier about losing a job, then one spends more time in unemployment.

As in the previous table, the OLS results in specifications (1) to (4) are similar to the StCox duration model in specifications (5) to (8). Women, the young and the highly educated spend less time in unemployment. When more people are jobless in one's region, duration increases. Unemployment benefits also push individuals to keep looking for a job longer (their reservation wage is higher). Having an unemployed spouse is associated with longer own unemployment spells. Specifications (4) and (8) are the most complete ones, and they show that the coefficient for $\Delta$ Hap is significant at the $1 \%$ level. Since the change in well-being is negative, it suggests that the more an individual says she suffers from losing a job, the quicker she returns to work. Specification (3) confirms this intuition: those who report a loss spend less time in unemployment. The results suggest that a one point increase in happiness (when losing a job) is associated with a 0.3 month increase in unemployment duration, even after controlling for other factors. The proportional hazard model confirms the OLS results. Those who suffered more upon the entry into unemployment have a higher hazard rate out of it. Thus, $\Delta$ Hap is negative, the less one is hurt by unemployment, the lower the hazard rate out of unemployment.

A sizeable proportion of the those entering unemployment end up leaving the labor force altogether. The duration model presented so far does not distinguish between those leaving unemployment to return to work $v s$ those leaving unemployment to be out of the labor force. In our sample, I identify 356 spells that end with the individual leaving the labor force. Many of these individuals end up re-entering the labor force in subsequent years, sometimes in the immediate year after, but for the sake of robustness, I run the following two tests. The first test consists of checking whether my results hold for the reduced sample of those who re-enter employment after unemployment. This is done in columns (4) and (6) of Table 10. The results show that $\Delta$ Hap predicts well the return to work for those who choose to stay in the labor force. In the second test, I create a dummy that is equal to one when an individual's spell ends in a return to employment and is equal to zero when the spell leads to exiting the labor force. A probit of the spell leading to 
return is then performed in which $\Delta H a p$ is included as a control variable. The results, presented in Table 13 show that $\Delta$ Hap does not predict the exit from the labor force.

Table 12 confirms the link between increased search and a shorter duration of unemployment. In specifications (2) to (4), the coefficient of job search is significant and shows that those who report searching for a job have a lower duration of unemployment. Moreover, the inclusion of job search is not affecting the significance of the other standard control variables (not reported). Table 12 in the Appendix is important because it proves that even after controlling for job search, the log of benefits received, and the log of yearly income, the coefficient for $\triangle H a p$ is unchanged.

I also look into the direction of the causality to show that it is not the duration of unemployment which is affecting happiness. Unemployment duration might affect well-being through a habituation effect. In their review of unemployment-related psychology findings, Darity and Goldsmith (1996) describe three phases of emotional response after a job loss. These consist of first shock phase where optimism st ill predominates, followed by a phase of pessimism and helplessness, and finally a phase of fatalism feelings with habituation.

If individuals adapt to being jobless, we should observe a higher well-being in longterm unemployed than in those who recently lost their job. Controlling for individual effects, we should observe among the unemployed a rise in well-being with time

Table 13 Likelihood of an Unemployment Spell Ending in a Return to Employment. Probit

\begin{tabular}{|c|c|c|c|c|}
\hline & $\begin{array}{c}\text { (1) } \\
\text { Return to Emp }\end{array}$ & $\begin{array}{c}\text { (2) } \\
\text { Return to Emp }\end{array}$ & $\begin{array}{c}\text { (3) } \\
\text { Return to Emp }\end{array}$ & $\begin{array}{c}\text { (4) } \\
\text { Return to Emp }\end{array}$ \\
\hline \multirow[t]{2}{*}{$\Delta$ Hap } & & & -0.0131 & \\
\hline & & & $(0.0100)$ & \\
\hline \multirow[t]{2}{*}{ Loss } & & & & 0.0304 \\
\hline & & & & $(0.0808)$ \\
\hline \multirow[t]{2}{*}{ Men } & $0.611^{* * *}$ & $0.603^{* * *}$ & $0.602^{* * *}$ & $0.604^{* * *}$ \\
\hline & $(0.0791)$ & $(0.0838)$ & $(0.0839)$ & $(0.0839)$ \\
\hline \multirow[t]{2}{*}{ Ed: Medium } & 0.0216 & -0.0467 & -0.0490 & -0.0475 \\
\hline & $(0.0927)$ & $(0.0952)$ & $(0.0952)$ & $(0.0952)$ \\
\hline \multirow[t]{2}{*}{ Ed: High } & $0.335^{* * *}$ & $0.200^{*}$ & $0.200^{*}$ & $0.200^{*}$ \\
\hline & $(0.105)$ & $(0.111)$ & $(0.111)$ & $(0.111)$ \\
\hline \multirow[t]{2}{*}{ Age } & $0.109^{* * *}$ & $0.114^{* * *}$ & $0.114^{* * *}$ & $0.114^{* * *}$ \\
\hline & $(0.0253)$ & $(0.0259)$ & $(0.0259)$ & $(0.0259)$ \\
\hline \multirow[t]{2}{*}{ Separated } & $0.296^{* *}$ & $0.376^{* * *}$ & $0.372^{* * *}$ & $0.376^{* * *}$ \\
\hline & $(0.121)$ & $(0.126)$ & $(0.126)$ & $(0.126)$ \\
\hline \multirow[t]{2}{*}{ Never Married } & $0.310^{* *}$ & $0.395^{* * *}$ & $0.391^{* * *}$ & $0.394^{* * *}$ \\
\hline & $(0.123)$ & $(0.125)$ & $(0.126)$ & $(0.125)$ \\
\hline \multirow[t]{2}{*}{ Constant } & $-1.772^{* * *}$ & $-2.404^{* * *}$ & $-2.395^{* * *}$ & $-2.418^{* * *}$ \\
\hline & $(0.518)$ & $(0.597)$ & $(0.596)$ & $(0.600)$ \\
\hline Observations & 1,338 & 1,334 & 1,334 & 1,334 \\
\hline Individual Controls & Yes & Yes & Yes & Yes \\
\hline Household Controls & Yes & Yes & Yes & Yes \\
\hline Income & No & Yes & Yes & Yes \\
\hline Region Dummies & No & Yes & Yes & Yes \\
\hline
\end{tabular}

Standard errors in parentheses. ${ }^{* * *} \mathrm{p}<0.01,{ }^{* *} \mathrm{p}<0.05,{ }^{*} \mathrm{p}<0.1$.

Loss is a dummy $=1$ when an individual reports a loss of happiness upon losing his job.

$\Delta$ Hap measures the initial change in happiness when becoming unemployed. Given that most observations of Diff-hap are negative, the results have to be interpreted as follows: if happier about losing a job, then one spends more time in unemployment. 
spent in unemployment. However, upon comparing well-being across different categories of unemployed, one cannot rule out a sample selection issue - arising in pooled regressions ${ }^{19}$. That is why pooled regressions yield different estimates than panel data regressions. Using panel data (individual fixed effects) is the proper way to estimate the impact of duration on well-being. Clark (2006) does this exercise using three European panel data sets. For the pooled data, he uses an interaction term between duration and unemployment. He finds that panel data does not support the hypothesis of habituation, when using the GSOEP and the ECHP ${ }^{20}$, but the results are not significant using the BHPS. The same exercise is executed in Table 14 and is explained below.

Table 14 estimates the effect of unemployment duration on well-being using a fixedeffect logit. Using pooled data in specifications (1) to (3) and an interaction term between unemployment and its duration, I found that unemployment duration is positively associated to well-being. However, if one controls for individual fixed-effects - in specifications (4) to (6) - then duration is no longer associated to well-being. This hints at the fact that duration is associated with the individual fixed-effects but not directly with well-being. The transition matrix shown before provides evidence that staying in unemployment has no different effect on well-being than staying in employment. The panel specifications (4 to 6) regress the change in well-being to the change in unemployment duration. The results show that the coefficient of duration is not significant. Hence, it can be said that the effect of unemployment on well-being is independent from its duration.

The last robustness check is performed in Table 5. Individuals are interviewed only once a year, but the unemployment spell could have started at any time in the previous 12 months. There is hence an under-representation of shorter unemployment spells. I check whether $\triangle H a p$ is dependent on the time having spent in unemployment before being interviewed by limiting the observations to spells that have happened in the last 11 months. I find no effect of the timing of the interview on $\Delta$ Hap, no matter the specification (fixed effects or pooled) or the gender (the result holds for both genders). The results confirm the finding of Gielen and Van Ours (2014) using German data: they also find no effect of interview time since unemployment on $\Delta H a p$.

\section{Conclusion}

Upon losing their job, workers report, on average, a fall in their subjective well-being, and this fall is higher for men than for women. Although this finding is frequent in the literature, few papers have attempted at exploiting the heterogeneity in this fall. I find a large heterogeneity: some feel better, while others feel worse when losing their job. This individual heterogeneity is hard to predict using the typical observable controls. Job search

Table 14 Testing Habituation to unemployment $1 / 2$

\begin{tabular}{|c|c|c|c|c|c|c|}
\hline & $(1)$ & (2) & (3) & (4) & (5) & (6) \\
\hline & GHQ & GHQ_men & GHQ_wom & GHQ_FE & GHQ_FE_men & GHQ_FE_wom \\
\hline \multirow[t]{2}{*}{ ep_duration } & $0.0167^{* * *}$ & $0.0151^{* * *}$ & $0.0141^{* * *}$ & 0.00656 & 0.00439 & 0.0159 \\
\hline & $(0.00238)$ & $(0.00270)$ & $(0.00480)$ & $(0.00514)$ & $(0.00539)$ & $(0.0133)$ \\
\hline \multirow[t]{2}{*}{ Constant } & $8.753^{* * *}$ & $9.029^{* * *}$ & $8.372^{* * *}$ & $8.947^{* * *}$ & $9.255^{* * *}$ & $8.344^{* * *}$ \\
\hline & $(0.0674)$ & (0.0819) & $(0.116)$ & $(0.105)$ & $(0.122)$ & $(0.222)$ \\
\hline Observations & 5342 & 3396 & 1946 & 5342 & 3396 & 1946 \\
\hline R-squared & 0.009 & 0.009 & 0.004 & 0.774 & 0.748 & 0.805 \\
\hline
\end{tabular}


theory suggests that the relative value of a job, with respect to being unemployed, should predict the job search effort. This paper exploits this variation in the fall of happiness and finds that men reporting feeling worse when losing their job are more likely to be actively looking for a job, and this increased search translates into shorter unemployment spells. The causality direction goes from the fall in happiness to the search effort, as one precedes the other, and tests of habituation to unemployment are rejected. The results do not hold when the analysis is performed on the women-only sample. They do hold however when interacting the change in happiness with gender, which leads the author to believe that the disappearance of significance is due to the reduced number of observations for women while the regressions still try to control for many fixed effects.

These results are important because they shed light on our understanding of job search effort. As predicted by theory, search effort is positively dependent on $V_{e}-V_{u}$, the difference in well-being an individual reports between being employed and jobless. As the payoff from being employed rises (falls), the unemployed will search more (less), and this translates into the a shorter (longer) unemployment spell. The gender difference in the results is puzzling and should be the focus of further research. Gielen and Van Ours (2014) is the only previous study attempting to do the same. They used a different dataset (from Germany), and they also found that a fall in happiness predicts job search. But their results show no link between job search and unemployment duration. This could be due to their use of life satisfaction instead of SWB and their use of a dichotomous variable, whereas I make full use of the continuity of SWB.

Finally, the results have to be seen as providing evidence that labor supply is an important determinant of unemployment. There is a large variance in search effort, and at least some of the unemployed are not looking for jobs because the payoff, in utility terms, is not large enough. Labor market activation programs should be especially useful and targeted to those workers.

\section{Endnotes}

${ }^{1}$ Clark and Oswald (1998) find that the income loss from losing a job explains only a quarter of the drop in well-being.

${ }^{2}$ Proponents of this idea highlight the negative psychological impact of being unemployed. Summaries of the literature can be found in (Fryer and Payne 1986; Warr 1987; Warr et al. 1988; Feather 1990). Argyle (2002) is a reference book in social psychology with an extensive chapter on the GHQ measure and another one on unemployment. Darity and Goldsmith (1996) provide a broad summary of the social psychology literature on unemployment.

${ }^{3}$ The effect of employment on SWB is not properly identified as we only observe transitions, and there might be a selection bias on transitions: something else can be causing both transitions and unhappiness.

${ }^{4}$ In 1999, 1,500 households were added from both Scotland and Wales. In 2001, another 2,000 households were added from Northern Ireland. More information can be found on the BHPS at https://www.iser.essex.ac.uk/bhps.

${ }^{5}$ There are 12 questions, and the score ranges from 0 to 12 . I use an "inverted Caseness score": individuals start with a score of 12, and for each question in which they are fairly or highly stressed, they lose one point. The GHQ score is widely used by psychiatrists: individuals with low Caseness scores are eligible for psychiatric treatment (Argyle 2002). 
${ }^{6}$ In the calculation of $\Delta$ Hap, I exclude those entering unemployment from a selfemployment status as the self-employed may have more discretion in choosing when and if to become unemployed. Given the more voluntary characteristic of the unemployment of those who were self-employed, their subsequent job search behavior is likely to be of a different nature, and the possibility to leave unemployment is also likely to be different since they may have more opportunities to start their own business.

${ }^{7}$ Individuals might feel the incentive to over-report their job search, if for example they feel that the benefits they receive are dependent on reporting they have been actively looking for a job. As long as the over-reporting just adds noise to the real measure of job search, the variable will be useful, albeit imprecise. However, if the over-reporting is correlated with $\Delta H a p$, then the results that follow will be biased.

${ }^{8}$ Spells longer than 8 years are (arbitrarily) taken out of the sample. They are outliers irrelevant to the present analysis and bias the results.

${ }^{9}$ Selection issues could explain this difference. Participation rates are higher for men than for women ${ }^{10}$, so it is possible that working women differ significantly from their non-working peers, whereas this is less the case for men.

${ }^{10}$ Women's participation rates have increased from 70\% to almost 75\% between 1991 and 2006 (the years covered in this survey). Men participation rates are above $85 \%$.

${ }^{11}$ Since 1996, unemployment benefits are given through the Job seeker's allowance (JSA) program, which posits conditions to those enrolled to ensure they are actively engaged in job search. The JSA has two components. The first component is contribution-based, and is given for at most of 6-months and for a maximum weekly value of 65 pounds (in 2010). The second component is income-based, also with a maximum of 65 pounds per week, and given only if the claimant as an income level below a certain threshold.

${ }^{12}$ (Moffitt 1985; Meyer 1990; Van Ours and Vodopivec 2006; Dormont and Fougère 2001) all find, using data from different countries, that the exit rate from unemployment to employment rises sharply as the end of the entitlement period approaches. See Card et al. (2007) for a review of findings.

${ }^{13}$ The dummy loss is constructed using $\triangle H a p$ and differentiates between those reporting a drop in happiness and those whose happiness does not fall upon losing their job.

${ }^{14}$ The reverse causality (search causing unhappiness) is avoided here because we are using the initial drop in happiness, which predates the search, is measured only once, and is time-invariant.

${ }^{15}$ This result also confirms the prediction of Clark and Lucas (2006) that sample selection bias arises if one uses pooled data OLS regressions to estimate the impact of unemployment duration on well-being. It seems that those feeling worse leave unemployment sooner than the others.

${ }^{16}$ the self-employed transitioning into unemployment are for now kept apart.

${ }^{17}$ Out of the labor force includes: maternity leave, retirement, long-term sick/disabled, or in training.

${ }^{18}$ Estimation (1) uses the dummy loss instead of the continuous variable $\Delta H a p$ as it makes the interpretation of the results easier.

${ }^{19}$ Through a shift-share mechanism. Those who stay unemployed longer are different: those suffering the most might have left to inactivity or back to work. Those suffering less from unemployment stay jobless: hence, a selection bias arises in cross-section specifications. 
${ }^{20}$ GSOEP is the German Socio-Economic Panel; ECHP is the European Community Household Panel.

\section{Appendix}

\section{Is the GHQ-12 a good measure of well-being?}

As presented by Argyle (2002), the 12-item version of the GHQ is a good test for the following reasons. First, it has internal coherence. The 12 items correlate with each other: the Cronbach alpha is high. Second, the scores are stable over time but sensible to changes when the individual reports going through current hassles. Third, the score is correlated to reports by others who know the subject and also to daily reports of moods, to cognitive measures and to reports from qualitative interviews. Fourth, the "immediate mood bias" is not likely to affect GHQ because the questionnaire asks questions related to the past weeks. Positivity bias is present in all types of surveys. Everyone is overconfident - except chronic depressives. Fifth, scales are comparable across individuals. The 12 questions used to build the GHQ-12 are as follow : "Have you recently..."

1. ...been able to concentrate on whatever you are doing?

2. ...lost much sleep over worry?

3. ... felt constantly under strain?

4. ...felt you could not overcome your difficulties?

5. ... been feeling unhappy or depressed?

6. ... been losing confidence in yourself?

7. ... been thinking of yourself as a worthless person?

8. ... been able to enjoy your normal day-to-day activities?

9. ... been able to face up to problems?

10. ... been feeling reasonably happy, all things considered?

11. ... felt capable of making decisions about things?

12. ...felt that you were playing a useful part in things?

For question 1, the responses are: Better than usual (1); Same as usual (2); Less than usual (3); Much less than usual (4).

For questions, 2 to 7, the responses are: Not at all (1); No more than usual (2); Rather more than usual (3); Much more than usual (4).

For questions 8 to 12, the responses are: More so than usual (1); About same as usual (2); Less so than usual (3) Much less than usual (4).

\section{Competing interests}

The IZA Journal of Labor Economics is committed to the IZA Guiding Principles of Research Integrity. The author declares that he has observed these principles.

\section{Acknowledgments}

This paper was presented at the IZA summer school in 2012, at the Search and Matching Workshop in Rouen in 2012 and at the Public Policy lunch seminar at the Paris School of Economics. I really appreciated the feedback given by Bruno Decreuse, Anne Gielen, Susan Vroman, Jim Albrecht and Thomas Piketty. This paper is based on one chapter of my dissertation at the Paris School of Economics. I would like to thank all the members of my thesis committee, Claudia Senik, Andrew Clark and Luc Behaghel, for the constant support they gave me as I worked on completing this paper. This paper was originally developed from my master's thesis, and I am grateful to Andrew Clark for his guidance. The Author would like to thank the anonymous referee.

Responsible editor: Pierre Cahuc 


\section{References}

Argyle M (2002) The psychology of happiness. (2 ed.). Routledge, New York NY

Blanchflower D (2001) Unemployment, well-being, and wage curves in Eastern and Central Europe. J Jpn Int Econ 15(4):364-402

Blanchflower, D (2004) Well-being over time in Britain and the USA. J Publ Econ 88(7-8):1359-1386

Card D, Chetty R, Weber A (2007) The spike at benefit exhaustion: leaving the unemployment system or starting a new job? Am Econ Rev 97(2):113-118

Clark A (2003) Unemployment as a social norm: psychological evidence from panel data. J Labor Econ 21 (2):323-351

Clark A (2006) A note on unhappiness and unemployment. Working Paper - Paris School of Economics 52(4):291-308

Clark A, Lucas R (2006) Do people really adapt to marriage? J Happiness Studies 7(4):405-426

Clark A, Oswald A (1998) Comparison-concave utility and following behaviour in social and economic settings. J Publ Econ 70:133-155

Clark AE, Oswald AJ (1994) Unhappiness and unemployment. Econ J 104(424):648-659

Darity W, Goldsmith A (1996) Social psychology, unemployment and macroeconomics. J Econ Perspect 10(1):121-140

Deaton A, Kahneman D (2010) High income improves evaluation of life but not emotional well-being. Proc Natl Acad Sci 107(38):16489-16493

DiTella R, Macculloch RJ, Oswald AJ (2001) Preferences over inflation and unemployment: evidence from surveys of happiness. Am Econ Rev 91(1):335-341

Dormont B, Fougère D (2001) L' effet de l' allocation unique dégressive sur la reprise d' emploi. Economie et Statistique 343:3-28

Feather NT (1990) The Psychological Impact of Unemployment. (Springer S ed.). Springer, New York

Frey B, Stutzer A (2001) Happiness and economics. Princeton University Press, Princeton

Fryer D, Payne R (1986) Being unemployed: a review of the literature on the psychological experience of unemployment. In: Cooper C, Robertson I (eds). International review of industrial and organizational psychology. Wiley, London

Gielen AC, Van Ours JC (2014) Unhappiness and job finding. Economica 81(323):544-565

Goldberg DP (1972) The detection of psychiatric illness by questionnaire. Oxford University Press, Oxford

Green F (2010) Well-being, job satisfaction and labour mobility. Labour Econ 17(6):897-903

Haisken-DeNew JP, Kassenböhmer SC (2009) You're fired! the causal negative effect of entry unemployment on life satisfaction. Econ J 119(536):448-462

Hanglberger D, Merz J (2011) Are self-employed really happier than employees? An approach modelling adaptation and anticipation effects to self-employment and general job changes. Iza Discussion Paper 5629, Institute for the Study of Labor (IZA).

Jackson P, Stafford E, Banks M, Warr P (1983) Unemployment and psychological distress in young people: the moderating role of employment commitment. J Appl Psychol 68:525-535

Jahoda M (1982) Employment and unemployment: a social-psychological analysis. Cambridge University Press

Korpi T (1997) Is utility related to employment status? Employment, unemployment, labor market policies and subjective well-being among Swedish youth. Labour Econ 4:125-147

Meyer B (1990) Unemployment insurance and unemployment spells. Econometrica 58(4):757-782

Moffitt R (1985) Unemployment insurance and the distribution of unemployment spells. J Econometrics 28:85-101

Mortensen DT (1977) Unemployment insurance and job search decisions. Ind Labor Relat Rev 30(4):505-517

Ours Van JC, Vodopivec M (2006) How shortening the potential duration of unemployment benefits affects the duration of unemployment: evidence from a natural experiment. J Labor Econ 24(2):351-378

Warr P (1987) Work, unemployment and mental health. Clarendon, Oxford

Warr P, Jackson P, Banks MH (1988) Unemployment and mental health: some British studies. J Soc Issues 44(4):47-68

Winkelmann L (1998) Why are the unemployed so unhappy? Economica 65(257):1-15

Woittiez I, Theeuwes J (1998) Well-being and labour market status. In: Jenkins S, Kapteyn A, Van Praag B (eds). The distribution of welfare and household production: international perspectives (Cambridge ed.). Cambridge University Press, Cambridge

\section{Submit your manuscript to a SpringerOpen ${ }^{\odot}$ journal and benefit from:}

- Convenient online submission

- Rigorous peer review

- Immediate publication on acceptance

- Open access: articles freely available online

- High visibility within the field

- Retaining the copyright to your article

Submit your next manuscript at $\boldsymbol{\triangleright}$ springeropen.com 